\title{
Research \\ Observations of Everyday Biodiversity: a New Perspective for Conservation?
}

\author{
Alix Cosquer $^{1,2}$, Richard Raymond $^{2}$ and Anne-Caroline Prevot-Julliard ${ }^{1,3}$
}

\begin{abstract}
Public involvement is one of the keys to achieving biodiversity conservation goals. Increasing public involvement in conservation activities requires investigation into what makes people more aware of nature, especially in an ordinary and local context, in their everyday lives. Among the initiatives developed to increase the public's awareness of conservation issues and individual environmental practices, citizen-science programs are based on an invitation to observe and survey nature. In our study, we examined the consequences of participation in a participative citizen-science program that takes place in an everyday-life context on individuals' knowledge and beliefs about biodiversity. This program, the French Garden Butterflies Watch, is addressed to the non-scientifically literate public and is run by the French National Museum of Natural History (MNHN). We examined the ways increased knowledge or strengthened beliefs or ideas about biodiversity can foster proconservation attitudes and behavior. We explored how repeated interactions with nature influence the development of knowledge in this area, and how these repeated observations of biodiversity become integrated into complex cognitive processes over time and space. We showed that repeated observations of nature can increase individual knowledge and beliefs. Our results brought out three important conclusions: (1) conservation issues must be integrated into a wider network of social relationships; (2) observing everyday nature often makes people consider its functional and evolutionary characteristics; and (3) scientific knowledge seems necessary to help people to develop their own position on ecosystems.
\end{abstract}

Key Words: Citizen science; cognitive processes; common knowledge; conservation psychology; everyday life; Garden Butterflies Watch; ordinary biodiversity; planned behavior theory; self-learning

\section{INTRODUCTION}

Despite international mobilization since 1992, the international objective of halting the decline in biodiversity by 2010 has not been achieved (CBD-UNEP 2010). Many paths have already been explored to tackle biodiversity decline. Early conservation approaches focused on ecosystems reservation and restoration (Palmer et al. 1997). However, many authors progressively underlined problems encountered with this exclusive approach (Ladkin 2005, Brockington et al. 2006). They suggest considering all environments, and especially anthropized environments (Rosenzweig 2003, Prévot-Julliard et al. 2012).

Due to this growing anthropization, areas managed by people are increasing. Therefore, the involvement and commitment of all stakeholders are key factors in the success of projects (Harrison et al. 1998, Alberti et al. 2003, Novacek 2008). Stakeholders that need to be involved include national and local authorities, elected representatives, and nongovernmental agencies (NGOs), but also citizens. Indeed, most everyday behaviors have a direct or indirect impact on biodiversity, especially if we consider the sum of all individual actions (Davies et al. 2009, Goddard et al. 2010).

Kollmus and Agyeman (2002:240) defined pro-environmental behavior as "behavior that consciously seeks to minimize the negative impact of one's actions on the natural and built world." We propose a similar definition for pro-conservation behavior, which, in particular, includes intentional components. One way to encourage the link between intention and conservation-friendly behavior is to increase personal experiences of nature (Clayton and Myers 2009). However, several authors have underlined the growing disconnection of people from nature and biodiversity (Pyle 2003). One hypothesis is that people are paying less and less attention to the ordinary plants and animals within their everyday lives (Miller 2005), especially in urban areas (Turner et al. 2004). If this is indeed the case, then increasing public involvement in conservation activities requires investigation into what makes people more aware of nature (Miller 2006), especially in an ordinary and local context, through their everyday lives.

This paper addresses the question of public involvement in biodiversity issues. It takes place in the field of conservation psychology (Saunders 2003, Schultz 2011) and the theory of planned behavior or "value-belief-action" (Zimbardo and Ebbsen 1969, Fishbein and Ajzen 1975, Ajzen 1991, Corraliza 2000). This theory formalizes relationships among individuals' knowledge, perception, and actions. Knowledge is often presented as a necessary cognitive step for people to adopt intentionally pro-conservation behavior (Staats 2003, Chatzisarantis et al. 2007). However, other authors have suggested that knowledge acquisition must go along with other factors before environmental behavior patterns emerge (Rozzi et al. 2006, Chawla and Cushing 2007, Houde 2007, Gonzalez 
et al. 2009). These factors can be ethical (Hines et al. 1986, Callicott 1999), emotional (Pooley and O'Connor 2000, Brady 2003, Selman et al. 2010), practical (Pruneau et al. 2000, Millennium Ecosystem Assessment 2005), or contextual (Blake 2001, Enserink et al. 2007, Dolnicar and Gruen 2009).

Many initiatives have already been developed to increase the public's awareness of conservation issues and environmental practices, especially by seeking to increase knowledge about biodiversity (Evely et al. 2011). Among these initiatives, participatory approaches combine the contribution of knowledge (brought by scientific discourses and environmental observations) with the consideration of individuals' personal beliefs and attitudes, in specific contexts (Kelsey 2003). Among them, citizen-science programs are based on an invitation to observe and survey nature (Cooper et al. 2007).

In citizen-science programs, the public collects information that will be used by scientists to study the dynamics of biodiversity (Evans et al. 2005, Schwartz 2006, Schmeller et al. 2009).The first objective of these biodiversity observations is data collection: public participation enables collection of copious data across large spatial and temporal scales. The second objective is public education (Brewer 2006, Couvet et al. 2008), aimed at increasing scientific literacy and individuals' participation in biodiversity conservation. Public education is perceived as a necessary step for the implementation of individual actions toward biodiversity (Hungerford and Volk 1990). However, if collected data on biodiversity are indeed used for scientific purposes (e.g., Bergerot et al. 2010a, b), the educational dimension of these observations is still largely unexplored (but see, e.g., Brossard et al. 2005). Moreover, claimed education objectives concern "science education" (Cooper et al. 2007, Bonney et al. 2009a, b), i.e., the increase of scientific knowledge. Little is said about the place of empirical and local knowledge of volunteers about biodiversity and about the evolution of all these kinds of knowledge during the participatory process.

The development of a citizen-science project requires an attentive design (Bonney et al. 2009b), which depends on the pursued objectives, i.e., scientific data gathering and public education. The different types of citizen-science programs can be analyzed through different related typologies (Danielsen et al. 2010). The first one is the degree of public involvementfrom data collecting to a collaboratively generated definition of the scientific question-(Cooper et al. 2007, Bonney et al. 2009a). The second is related to the participants' level of scientific literacy: we define the literate public as people possessing an established knowledge regarding biodiversity. Conversely, we define the non-literate (or lay) public as people with no previous naturalist knowledge. A third, less implemented, typology could refer to the observation context: surveys can take place in a specific, extraordinary context (that is, volunteer conservation programs), where participants sometimes travel abroad to participate for a pre-defined duration, or in an ordinary context, where surveys take place in a familiar environment, in an everyday life context.

In a local observation context, we argue that immediate and repeated exposure to nature and the outdoor environment is important in the acquisition of different types of knowledge. Indeed, contact with the natural environment could enable participants to confront their beliefs and knowledge with the external reality. The repetition of this immediate experience may help confirm, invalidate, or anchor some of these beliefs.

The fact that public participation takes place in an everyday life environment (i.e., ordinary, familiar, sometimes private), in which people have habits and are used to act, may reinforce the feeling of an ordinary observation and action and leaves a place for a very personal construction of knowledge. The familiar setting where initiatives take place may contribute to the interaction with individuals' everyday preoccupations, such as quality of life, consumption choices, etc. (Brechin and Kempton 1994). Within individuals' perceptions, potential emotional and contextual aspects may interact with scientific knowledge (see Stern 2000, Sturgis and Allum 2004).

We examined the consequences of individuals' engagement in a citizen-science program (described as "contributory"Bonney 2009a — and developed with a lay public in mind) that takes place in an everyday life context. This program is the French Garden Butterflies Watch, run by the French Museum of Natural History (MNHN) and the NGO Noé-Conservation since 2006 (http://opj.mnhn.fr/).

We focused on individuals' biodiversity knowledge and awareness: we looked into the conditions that foster the acquisition of individual knowledge and awareness relating to biodiversity. We defined knowledge more widely than scientific knowledge, including beliefs and ideas as well. We explored how repeated interactions with nature influence the ways in which this knowledge is disseminated and evolves.

We raised the following question: what influence do biodiversity observations fostered by citizen-science programs have on development of knowledge or beliefs about biodiversity? We explored this question at the individual and interpersonal level, at a local scale.

\section{MATERIAL AND METHODS}

\section{Garden Butterflies Watch}

In this program, garden owners are invited to identify and count butterflies in their gardens to supply a national database that supports scientific research. The protocol is deliberately very simple: observers are asked to identify and count the butterflies they see in their gardens and to indicate, for each month, the maximum number of individuals of each 
morphospecies they have observed simultaneously. The annual sampling season runs from March to October.

This program has some 3,500 to 4,000 participants every year. Noé-Conservation uses various tools to run the observers' network, some directly connected with butterfly counting (guide to identification of butterfly morphospecies, monthly count sheets), others concerning butterfly-friendly gardening (website, monthly newsletter), and an online forum where butterfly watchers can share their experiences.

Participation in the program is entirely voluntary. Observations are anonymous and contributors identified only by an email address and the location of their observation site. Participants are free to decide when and for how long they will proceed with their observations. The program encourages regular and repeated observation. Except for the butterfly identification guide and the monthly count sheets, there is no interaction between the observers and any reputedly better qualified authority. Finally, the observations take place in a private and familiar setting. All these features could potentially turn the Garden Butterflies Watch into a selflearning protocol that operates in addition to the educational content brought by the program. Indeed, if the protocol of observation is common for all participants (i.e., watching butterflies in the garden), individual consequences are different for each one. We chose to focus on these consequences.

\section{Method}

We used a classic anthropological approach (Goffman 1967) to analyze the consequences, for the butterfly watchers, of their participation through face-to-face interviews and observations of their gardens. To allow for the potential influence of human density and climatic conditions on their gardening practices, personal representations, and attentiveness to nature, we chose three contrasting areas for our investigations (Fig. 1): Ile-de-France (the greater Paris area: temperate climate, very high population density), the Mediterranean coast (Mediterranean climate, medium population density), and Brittany (oceanic climate, low population density).

The interviews took place from May to August 2009. Thirty individuals or families participating in the Garden Butterflies Watch were interviewed (respectively 12,10, and 8 in the three regions listed above). Participants were contacted by email, regarding their area of participation. We selected those who were first to respond for the interviews. Respondents were divided into three main profiles: retired people (over $60 \mathrm{yrs}$ old, $n=5)$, couples/adult with children $(n=21)$, and working people without children $(n=4)$. Their occupational categories varied, and most had completed some higher education (Table $1)$.
Fig. 1. Mapping of interviewees-France.

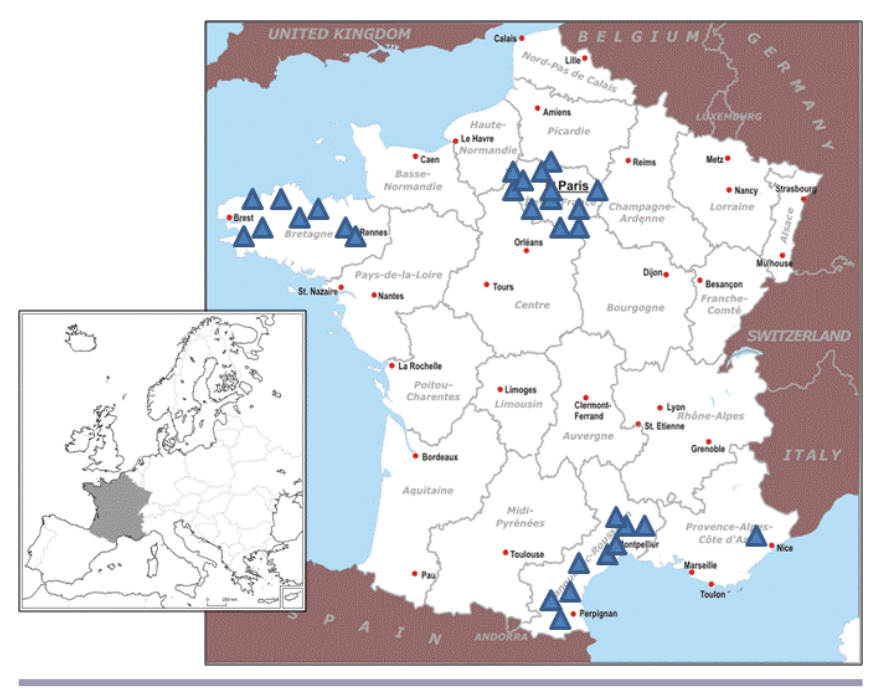

Table 1. Interviewees' educational and socioeconomic profiles.

\begin{tabular}{|c|c|c|c|}
\hline \multicolumn{2}{|l|}{ Education } & \multicolumn{2}{|l|}{ Social and Economic Situation } \\
\hline A Level (high school equivalent) & 4 & Executive & 1 \\
\hline Undergraduate degree & 9 & Employee & 17 \\
\hline Master's degree & 10 & Small business/Entrepreneur & 2 \\
\hline Doctorate & 3 & Retired & 4 \\
\hline Not Stated & 4 & $\begin{array}{l}\text { No professional occupation } \\
\text { Other }\end{array}$ & $\begin{array}{l}3 \\
3\end{array}$ \\
\hline Total & 30 & Total & 30 \\
\hline
\end{tabular}

About one-third $(n=12)$ of the respondents had environment or nature-related jobs. Twenty-one had joined the program from the start, 4 yrs before, and nine had been taking part for 3 yrs. They did not always participate on a regular basis.

The interviews were conducted by a single person in accordance with the comprehensive interview method described and theorized by Kaufmann (2008). The thematic guidelines we used to structure the interviews are given in Appendix 1.

The interviews lasted $1 \mathrm{~h} 30 \mathrm{~min}$ on average (40 min-3h30). Most of them $(n=24)$ took place in the respondents' houses, in the living room or in the garden. These interviews included, at a minimum, a tour of the garden. Two interviews were conducted on a café terrace close to the respondents' homes, three at the respondents' work places, and one in a public park near the respondent's workplace.

All interviews were recorded and transcribed. After 30 interviews, we reached saturation as the last interviews did not contribute to discovering anything new (Strauss 1987). We 
used grounded theory to analyze the collected data (Glazer 1992, Charmaz 2006): from the interviews, we identified core variables and coded them. General patterns were then inferred from the comparison of individual interviews; the number of concerned people for these general patterns was specified ( $n$ $=$ " $x$ "), and we chose representative quotes to highlight each specific result.

\section{RESULTS}

\section{Involvement in the Garden Butterflies Watch}

All respondents showed a general interest in environmental matters, but not particularly in biodiversity. Their definitions of the environment included both natural and social aspects.

The Garden Butterflies Watch is an open-access program available on the Internet. Participation in the program could, therefore, have followed a process specific to each individual navigating on the Web. In fact, their participation in the program started through different social networks, mostly structured by the popular media: press media (unspecified media $n=19$, audio press $n=1$, online press $n=3$ ), professional networks $(n=4)$, and social networks $(n=3)$. Only six people learned about the program through a nature- or biodiversityconnected network. Therefore, wanting to participate seemed to be connected more with positive and appealing values (fun, discovery, contribution to science) than with conservation.

This interpretation is borne out by two factual observations. First, most respondents $(n=24)$ stated they had little or very little competence as naturalists when they began to participate. Only one had any previous knowledge of butterflies. Their observation of butterflies, at the morphospecies level, began with their participation in the program. Second, many respondents $(n=23)$ were only involved in this particular citizen-science program. For the others, the Garden Butterflies Watch was the first citizen-science program they had become involved in.

The confidence people said they had in the MNHN seemed to contribute to their willingness to participate in the program $(n$ =12). They recognized two areas of competence at the MNHN: its naturalist and scientific qualifications and its operating proficiency. Their involvement rests to some extent on their pride in contributing at their own individual level to a largescale scientific program conducted by the MNHN, i.e., to something that goes beyond their individual interest. Participation thus seems connected with trust in science and positive values (e.g., quote 1).

\section{Quote 1}

I've always been interested in science. Here, well... it's a really modest contribution, but the idea that you can participate without having any scientific qualifications is precisely what I like...

(Man, forties, Ile-de-France, married, children, building contractor)
Personal engagement in the Garden Butterflies Watch can be formalized as a cognitive process that reaches beyond the individual to become social and cultural as well.

\section{Consequences for Observers of their Participation in the Garden Butterflies Watch}

Participating in the Garden Butterflies Watch, specifically in repeated observations of garden butterflies, had many consequences for the respondents. We identified three main non-exclusive consequences that concern a large number of participants: (1) increased attentiveness to and knowledge of butterflies $(n=29)$; (2) increased awareness of the ecological functioning of the immediate environment $(n=29)$; (3) discovering possibilities for situating oneself in relation to this environment $(n=28)$.

First, they began to look at garden butterflies in their daily lives. Most had little naturalist knowledge (especially about butterflies, $n=29$ ) and were unaware of biodiversity when they began to participate in the program (e.g., quote 2).

\section{Quote 2 \\ I come from a nearby village where people don't give a damn about nature. That's how I was raised. We destroyed things, people hunted. We destroyed without any sort of restriction and the habit stayed. Even I had it: all right, I have to prune the bushes, mow the grass, kill things, etc. Even insects, I mean everything. \\ (Man, fifties, Mediterranean coast, married, municipal employee)}

To become an observer, people have to see and count butterflies. Butterflies that people used to notice without being particularly interested are now given real attention. This attentiveness was new to many observers we met $(n=29)$, who discovered their number and their diversity (e.g., quote $3)$.

\section{Quote 3}

From the moment I started to watch butterflies, I was learning, getting to know them and it's true, I didn't know there was such diversity. And I think this is an extraordinary experience.

(Woman, fifties, Ile-de-France, married, children, no professional occupation)

It seems from our interviews that observing butterflies and identifying the different categories creates a self-perpetuating cycle: the better the observers are able to recognize different butterflies, the more they pay attention to them, which in turn improves their ability to recognize them (e.g., quote 4)...

\section{Quote 4}

We realized that we used to see butterflies, but not watch them, (...) they were part of the surroundings. And then we started to observe, we kept trying, it became a game. At the beginning, it was a bit difficult, we bought easy books (...). And it turned 
into a sort of a game.

(Woman, sixties, Mediterranean coast, married, children, no profession)

The second consequence of participating in the program was the realization that butterflies are part of a dynamic and evolutionary system that goes beyond butterflies themselves $(n=29)$. This realization happens with the observation of butterflies' relation with their environment (life cycle and needs, climate, vegetation...). The dynamics of this ecological system were approached through seasons or through the relationships among butterflies, caterpillars, host plants, and the local environment (e.g., quote 5).

\section{Quote 5}

I do my best to attract them [butterflies]. Or at least to keep them. This year I'm a bit worried because I haven't seen any caterpillars. I saw some in March, a lot of caterpillars asleep. And finally I didn't see the butterflies hatch. (...) I have untilled land, with nettles, where I would expect to find caterpillars. But there aren't any. (...) So it's a bit worrying. I grow radishes that cabbage whites usually feed on. At the moment I have some very healthy radishes. I'm waiting for July to see how things evolve.

(Woman, thirties, Ile-de-France, married, children, teacher)

The observers probably had some knowledge of the life-cycle characteristics of butterflies, but with repeated observations, they were able to compare their theoretical knowledge with the reality of their ordinary environment. As they did so, these theoretical characteristics became more real, more evident.

For most respondents $(n=29)$, their grasp of the functional and dynamic characteristics of their environment extends beyond butterflies and their host plants (e.g., quote 6).

\section{Quote 6}

When we arrived here, more than 20 yrs ago, there were a lot of toads. Is it because of the summer of 2003, when it was particularly hot? I don't know. But they have almost disappeared. We have a lot of frogs, tree frogs, and green frogs too, but the toads are almost gone. (...) It's very strange. I don't know why.

(Woman, sixties, Mediterranean coast, married, employed in local NGO)

Finally, for most respondents $(n=28)$, garden butterflies have become an indicator of their own practices. The observation of garden butterflies contributes to their self-awareness, which leads to self-regulation of their own actions (e.g., quote 7).

\section{Quote 7}

Seeing butterflies in my garden is rather reassuring. I say to myself: 'well, if they're all right, then we must be doing something right'.

(Woman, thirties, Brittany, educator)

This process of self-awareness leads to the emergence of new individual behavior patterns. Many respondents $(n=26)$ had partly or more extensively changed their gardening practices in order to make their gardens more hospitable to butterflies or biodiversity in general. Some planted particular species (aromatic plants, Buddleia, etc.) or deliberately allowed adventitious plants to grow (nettles, valerian, brambles). Some changed their garden treatments or lawn-mowing habits (e.g., quotes 8 and 9).

\section{Quote 8}

Butterflies have made me plant more aromatic plants in the garden because, well... we already had some, but so that I could watch the butterflies, I decided to add some more, and that changed the garden's structure too.

(Man, forties, Brittany, married, children, town and country planning)

\section{Quote 9}

I count butterflies. It's a bit like trophy hunting, so the less insecticide I use, the more chances I have of seeing butterflies.

(Woman, thirties, Ile-de-France, married, children, teacher)

These cognitive processes do not reveal the nature of the values and representations that underlie people's relationships with butterflies and ecosystems. Some of these relationships can be aesthetic (aspect of butterflies or the garden), others may be connected to the individual satisfaction in gaining knowledge. However, the consequences with regard to selfawareness involve a set of values that extend beyond the individual to include cultural values.

\section{Consequences of Participation in the Garden Butterflies Watch on Social Relationships}

As well as individual consequences, participation in the program takes place within the broader framework of social networks.

Indeed, butterfly watching in a familiar context thus takes place within a social process. This network helps to disseminate ideas about biodiversity through a combination of established and empirical knowledge that results from interpretations of individual experiences. The connection between individual learning and social interaction is reinforced by people's desire to share experiences and by the integration of these new ideas and knowledge into the different social relationships that revolve around their environment.

First, participation in the Garden Butterflies Watch may be embedded in the social dissemination of naturalist knowledge, through nature guides $(n=15$, e.g., quote 10$)$. 


\section{Quote 10}

I am a naturalist, but as an amateur. I don't have much time to attend a course of lectures... so I usually take my books with me and learn in the field. I have bird identification books (...) and now of course I have butterfly identification books.

(Man, forties, Brittany, married, children, municipal employee)

Thus, although most respondents recognized their lack of qualifications as naturalists at the beginning of their involvement, many of them went on to gain empirical knowledge on observable biodiversity, supported by a combination of two different types of learning: (1) the acquisition of established naturalist or scientific knowledge and (2) the confrontation of this theoretical knowledge with the real world, through long-term observation of garden butterflies (see above). This second type of knowledge is highly contextual. However, the conjunction of the two learning processes contributes to a self-perpetuating cycle: nature guides and other resources highlight and promote individual observations, while individual observations in turn illustrate and support the quest for established knowledge through nature guides (e.g., quote 11).

\section{Quote 11}

Ilike to use nature guides with photographs, because I don't see so well with drawings. Each of us has a particular vision, colors for example can seem different from one person to another. (...) I don't always take my book with me (...) When I get home, I look in the book (...) and then if we go back to the same place, I know I'll be able to recognize what I've seen.

(Woman, thirties, Mediterranean Coast, building contractor)

This type of knowledge acquisition also seems to be a strong factor in making observers proud of gaining their knowledge. Almost all respondents $(n=29)$ wanted to share this knowledge and the underlying practices. Individual cognitive processes described above are, therefore, included in a web of explicit interpersonal relationships within the observers' immediate network of relationships (family, neighborhood, professional networks, etc.) (e.g., quote 12).

\section{Quote 12}

My youngest son is 5 yrs old; now (...) he knows three or four names and he's able to recognize them. Ifind that wonderful! (...) Before, when he saw a butterfly, he used to say: 'oh, there's a butterfly!'But today he says: 'Oh, look, it's a Peacock, a Large White, or a Brimstone...'

(Man, forties, Ile-de-France, married, children, building contractor)
The self-awareness processes we noted earlier have counterparts in social relationships. Butterflies, when already perceived as indicators of a garden's ecological quality, can become indicators of the quality of the observer's environment more generally, as the butterfly watchers begin to use their perceptions and knowledge to evaluate the practices of other people. All the respondents mentioned themes that go well beyond butterfly watching, such as local geography and how it is changing (e.g., quote 13).

\section{Quote 13}

We will see, because before there was no housing estate... Now, 40 houses have been built, so we'll see if it has an impact or not... But what I am sure of is that I now leave a small part of my garden fallow, and all the butterflies go there.

(Woman, thirties, Ile-de-France, married, children, geologist)

Observers can mobilize expertise in their neighborhood. Butterflies then become social mediators, in gardening practice $(n=2)$, local nature management $(n=4)$ or both $(n=$ 23 , e.g., quote 14).

\section{Quote 14}

When my neighbor uses garden treatments, which I don't, I can't go to see him to tell him not to do so, that wouldn't work. Instead, I bring him to my garden and show him what I do and what I have, and explain. Afterwards, he can agree or not, but at least...

(Woman, fifties, Mediterranean coast, married, children, Bed and Breakfast)

Moreover, repeated observations of garden butterflies and the resulting knowledge gained create an episteme. Although observers may never meet, most respondents $(n=24)$ expressed their opinion of belonging to a community. Although abstract, this episteme seems to strengthen the conditions in which new ideas and beliefs are acquired. Belonging to a community, even hypothetically, seems to legitimize shared beliefs. Nevertheless, all respondents would like to really share and compare their observations with others. This again confirms the importance of comparing ideas with reality to remove any suspicion of subjectivity or error (e.g., quote 15).

\section{Quote 15}

It's a good thing to develop a common awareness. (...) I think we don't exchange views enough. I feel a bit alone sometimes. We're looking for a bigger movement. And we are looking for information as well, because we are the only judges of our actions. Sometimes I think: 'well, that's not right, I should do things differently' and it would be good to have an outside opinion, even an analysis, because there are things we don't see. Because we are both judge 
and jury, it distorts the results a bit.

(Woman, forties, Mediterranean coast, married, children, computer specialist)

\section{DISCUSSION AND CONCLUSION}

In this analysis, we formalized several possible causes and consequences of participating in a citizen-science program, at both individual and social levels. We used a classic anthropological method. Our results are, therefore, only representative of the particular situations of the 30 respondents, not of all the consequences of repeated observations of garden butterflies. Moreover, our respondents had all been participating in the citizen-science program for more than 2 yrs, which was not the case for the great majority of the participants in this program. However, we found some constant processes in our sample, which also concurred with what we detected in a forum on the program initiated by NoéConservation (results not shown). This suggests that the results we present from the interviews may be more widely applicable, in contexts offering similar observation possibilities (i.e., in an everyday life context with a lay public).

We did not detect any difference in attentiveness to biodiversity among the three geographic regions we worked in. The respondents referred to daily contexts that differ with each geographic, cultural, and social situation. However, the individual, social, and cultural cognitive processes that we inferred from the interviews were similar, independent of their urban or climatic context.

We found that interviewees were environmentally concerned. This result is consistent with the findings of previous studies (Evans et al. 2005, Storksdieck et al. 2005). However, we showed that people engaged in Garden Butterflies Watch did not have previous specific knowledge about butterflies or biodiversity. These results suggest that environmental awareness does not necessarily include awareness regarding biodiversity and conservation stakes.

We identified different semantic dimensions to classify the respondents' connections toward environment: cognitive dimension (Rickinson 2001), where nature is described using scientific knowledge; affective dimension (Hides and Sparks 2008), where nature is described with emotional and affective terms; aesthetic dimension (Brady 2006), where nature is described by beauty or artistic terms; utilitarian dimension (Minteer and Collins 2005), where nature is viewed as providing services for humans; anthropomorphic dimension (Horowitz 2007), where nature (e.g., animals) is described by using human-centered terms; substitutive dimension (Wells and Lekies 2006), where nature is described as reflecting past events of individual history.

Despite its limitations, our study showed how ordinary observations of biodiversity can be important for the development of knowledge and awareness regarding local biodiversity. We showed as well that this increase in knowledge and awareness is related to the intentional implementation of local pro-conservation behavior. The underlying causes involve a whole series of interconnected relationships to nature or about nature, almost cognitive in this context, but also affective (quotes 3, 7), utilitarian (quote 5), or linked with individual histories (quote 2). This result is consistent with other studies that revealed that environmental behavior indeed results from multiple motivations (Lindenberg and Steg 2007, and references therein).

We showed that ordinary and repeated observations of nature can be an important way of increasing individual knowledge and awareness. These everyday observations are structured by different motivations (the aesthetics of butterflies or gardens, responsibility, curiosity, simplicity). These different aspects work closely together at different levels of individual, social, and cultural organization.

Our results refer to the theory of planned behavior (TPB, Ajzen 1991), which relates behavior to behavior intentions, which are mostly internally governed and to other unintended causes. Behavioral intentions are constituted by attitudes, subjective norms, and perceived control over the behavior. In accordance with this theory, we formulate three main discussion topics:

1. The ideas and beliefs that develop from attentive and repeated observations of nature can be brought into play to initiate or support new practices. Observed practices, directly related to the participation, include: (1) gardening practices (e.g., butterfly-friendly practices, such as planting particular species (aromatic plants, Buddleia, etc.), deliberately allowing adventitious plants (nettles, valerian, brambles) to grow, changing garden treatments and lawn-mowing habits) and (2) social practices (e.g., incentive to participate in the Garden Butterflies Watch, to change or improve gardening practices). Although no conclusion can be drawn about the relationship between pro-biodiversity and proenvironment behaviors, participation in the Garden Butterflies Watch positively reinforces individuals' attitudes regarding environment preservation.

Our results show that the awareness of biodiversity (here, the willingness to participate in the Garden Butterflies Watch) spreads in general social networks (i.e., the media), which are not necessarily connected to nature. Today, for most citizens, the social incentive of conserving biodiversity is not a value of sufficient importance to induce an individual to engage in proconservation behavior (e.g., Novacek 2008). As was proposed by Darner (2009, based on Ryan and Deci 2002), extrinsic motivations alone do not motivate people to act for environment. However, we have shown that environmental values or values linked with trust in science can be of particular importance in encouraging 
the acquisition of knowledge and practices. These intrinsic motivations may contribute to the internalization of pro-biodiversity knowledge, values, and norms. Indeed, as Ryan and Deci (2000) suggest, the more fully a motivation is internalized and integrated with one's self, the more it will be the basis for autonomous behavior. These results are consistent with previous studies that highlight the importance of social and local identity on behavior intentions, even when not connected with environmental values (Stedman 2002, Carrus et al. 2005).

2. Understanding the functional characteristics of nature (at least in part) helps people to work out their own position in relation to these dynamics. Indeed, we have shown that, whatever the motivations, observing everyday nature often leads people to consider its functional and evolutionary characteristics. Even if individual motivations for action can be aesthetic, ethical, utilitarian, or all of these at once, people still take an interest in the living and functional features of nature. Combining personal empirical observations and theoretical knowledge makes the newly acquired knowledge more robust (Ross et al. 2003).

Becoming aware of this functional system could help, at least partially, to re-establish people's connections with nature. These results confirm those of Rickinson (2001) and Meinhold and Malkus (2005). This is a move away from consumerism, where nature is objectified and embodied in objects, and where relationships change with moods and trends.

3. Furthermore, we suggest that scientific knowledge about biodiversity can become part of a common reference that can structure an episteme. Indeed, in the positions, however polymorphic, that people work out for themselves, scientific knowledge has an important place. Even limited scientific knowledge seems necessary for observers to develop their position on ecosystems, or the part of these ecosystems that lies within their grasp.

In our study, sharing common scientific knowledge (on butterflies) is creating so-called social identity (see Clayton and Myers 2009: chap. 4). It could be especially relevant for people who do not belong to already structured social groups relating to nature (environmental NGOs, farmers, anglers, hunters, etc.).

Combining these elements seems fundamental to achieving biodiversity conservation goals. This is what allows attention to be drawn to the functional features of nature and to the implicit processes that guide and structure most of our behavior. Bourdieu (1980) called this implicit process the "Habitus," Searle (1983) called it "Background," and many authors have confirmed its importance in accounting for observed patterns of behavior (in the theory of planned behavior, intention to act and behavior are based on individuals' attitudes toward the object (i.e., behavioral beliefs), as well as on social pressures and sense of control (that is, normative and control beliefs)).

Our findings offer a psychological contribution to the citizenscience field regarding programs for the lay public in an ordinary context. Concerning the citizen-science objective of data collection, it appears that participants, even when they are environmentally sensitized, do not possess a deep naturalistic knowledge. Required data must then be easy to watch, collect, and identify (e.g., common species or presented at a low level of identification, e.g., at the morphospecies level). This enables both large individual participation and relevant scientific studies.

Regarding the other citizen-science objective of education, conditions of participation and observation offer the opportunity to experience biodiversity individually and positively. Our research context underlines the existence of various conditions that foster the dissemination of knowledge about biodiversity. Garden butterfly watching takes place in a familiar setting, and observers are free to choose the time and the terms of their observations. Knowledge gained through participation seems to develop outside the usual specific and limited framework of environmental education (classroom presentations, naturalist excursions, etc.). On the contrary, the freedom given to observers and the familiar context in which the program operates favors the dissemination of ideas that develop among participants in their daily lives and their own cognitive frameworks. Their attentiveness to butterflies combines with their various everyday thoughts and, without even thinking about it, paying attention to butterflies becomes a habit, a reflex. It is the need to count and list butterflies that forms this habit, makes it explicit and establishes it as a deliberate goal, a conscious object. Clearly, then, one of the most important consequences of participation in the Garden Butterflies Watch is that people who had lost not only the habit but also the practice are once more learning to observe.

The repetition of this observation experience contributes to development of the self-learning processes. Self-learning contributes to (1) increased individual motivation to participate in a citizen-science program and to pursue observation and (2) development of individual care toward biodiversity (i.e., the combination of individuals' feelings, knowledge, and behavior, Clayton and Myers (2009)).

These kinds of citizen-science programs could help address the issue of individual disconnection with environment (Pyle 2003). Awareness and care could even be improved by the inclusion of environmental practices in broader, more complex, and multi-thematic networks of social relationships. 
Responses to this article can be read online at: http://www.ecologyandsociety.org/issues/responses. php/4955

\section{Acknowledgments:}

This study was conducted under the PICRI program of the Ilede-France regional council and the Communication Science Institute (ISCC). We thank the NGO Noé-Conservation for its support in contacting the observers, our colleagues for their helpful comments, and Susan Clayton for her careful reading.

\section{LITERATURE CITED}

Ajzen, I. 1991. The theory of planned behavior. Organizational Behavior and Human Decision Processes 50:179-211.

Alberti, M., J. M. Marzluff, E. Schulenberger, G. Bradley, C. Ryan, and C. Zumbrunnen. 2003. Integrating humans into ecology: opportunities and challenges for studying urban ecosystems, BioScience 53(12):1169-1178.

Bergerot, B., B. Fontaine, R. Julliard, and M. Baguette. 2010a. Landscape variables impact the structure and composition of butterfly assemblages along an urbanization gradient. Landscape Ecology, in press.

Bergerot, B., R. Julliard, and M. Baguette. 2010b. Metacommunity dynamics: decline of functional relationship along a habitat fragmentation gradient. PLOSONE 5:e11294. http://dx.doi.org/10.1371/journal.pone.0011294

Blake, D. E. 2001. Contextual effects on environmental attitudes and behavior. Environment and Behavior 33(5):708725. http://dx.doi.org/10.1177/00139160121973205

Bonney, R., H. Ballard, R. Jordan, E. McCallie, T. Phillips, J. Shirk, and C. C. Wilderman. 2009a. Public participation in scientific research: defining the field and assessing its potential for informal science education. A CAISE Inquiry Group Report. Center for Advancement of Informal Science Education (CAISE), Washington, D.C., USA.

Bonney, R., C. B. Cooper, J. Dickinson, S. Kelling, T. Phillips, K. Rosenberg,and J. Shirk. 2009b. Citizen science: a developing tool for expanding science knowledge and scientific literacy. BioScience 59(11):977-984.

Bourdieu, P. 1980. Le sens pratique. Éditions de Minuit, Paris, France.

Brady, E. 2003. Aesthetics of natural environment. Edinburgh University Press, Edinburgh, UK.

Brady, E. 2006. Aesthetics in practice: valuing the natural world. Environmental Values 15:277-291. http://dx.doi. org/10.3197/096327106778226202
Brechin, S. R., and W. Kempton. 1994. Global environmentalism: a challenge to the postmaterialism thesis? Social Science Quarterly 75:245-269.

Brewer, C. 2006. Translating data into meaning: education in conservation biology. Conservation Biology 20(3):689-691. http://dx.doi.org/10.1111/j.1523-1739.2006.00467.x

Brockington, D., J. Igoe, and K. Schmidt-Soltau. 2006. Conservation, human rights, and poverty reduction. Conservation Biology 20:250-252. http://dx.doi.org/10.1111/ j.1523-1739.2006.00335.x

Brossard, D., B. Lewenstein, and R. Bonney. 2005. Scientific knowledge and attitude change: the impact of a citizen science project. International Journal of Science Education 27:10991121. http://dx.doi.org/10.1080/09500690500069483

Callicott, J. B. 1999. Beyond the land ethic: more essays in environmental philosophy. State University of New York Press, Albany, New York, USA.

Carrus, G., M. Bonaiuto, and M. Bonnes. 2005. Environmental concern, regional identity, and support for protected areas in Italy. Environment and Behavior 37(2):237-257. http://dx. doi.org/10.1177/0013916504269644

Charmaz, K. 2006. Constructing grounded theory: a practical guide through qualitative analysis. Sage Publications, Thousand Oaks, California, USA.

Chatzisarantis, N. L. D., and M. S. Hagger. 2007. Mindfulness and the intention-behavior relationship within the theory of planned behavior. Personality and Social Psychology Bulletin 33:663-676. http://dx.doi.org/10.1177/0146167206297401

Chawla, L., and F. D. Cushing. 2007. Education for strategic environmental behavior. Environmental Education Research 13(4):437-452. http://dx.doi.org/10.1080/13504620701581539

Clayton, S., and G. Myers. 2009. Conservation psychology. Understanding and promoting human care for nature. WileyBlackwell, Chichester, UK.

Cooper, C. B., J. Dickinson, T. Phillips, and R. Bonney. 2007. Citizen science as a tool for conservation in residential ecosystems. Ecology and Society 12(2): 11. [online] URL: http://www.ecologyandsociety.org/vol12/iss2/art11/

Corraliza, J. A. 2000. Environmental values, beliefs, and actions: a situational approach. Environment and Behavior 32:832-848. http://dx.doi.org/10.1177/00139160021972829

Couvet, D., F. Jiguet, R. Julliard, H. Levrel, and A. Teyssedre. 2008. Enhancing citizen contributions to biodiversity science and public policy. Interdisciplinary Science Reviews33(1):95103. http://dx.doi.org/10.1179/030801808X260031

Darner R. 2009.Self-determination theory as a guide to fostering environmental motivation. Journal of Environmental Education 40:39-49. http://dx.doi.org/10.3200/JOEE.40.2.39-49 
Danielsen F., N. D. Burgess, P. M. Jensen, and K. PirhoferWalzl. 2010. Environmental monitoring: the scale and speed of implementation varies according to the degree of people's involvement. Journal of Applied Ecology 47:1166-1168. http://dx.doi.org/10.1111/j.1365-2664.2010.01874.x

Davies, Z. G., R. A. Fuller, A. Loram, K. N. Irvine, V. Sims, and K. J. Gaston. 2009. A national scale inventory of resource provision for biodiversity within domestic gardens. Biological Conservation 142(4):761. http://dx.doi.org/10.1016/j.

biocon.2008.12.016

Dolnicar, S., and B. Gruen. 2009. Environmentally friendly behavior: can heterogeneity among individuals and contexts/ environments be harvested for improved sustainable management? Environment and Behavior 41(5):693-714. http://dx.doi.org/10.1177/0013916508319448

Enserink, B., M. Patel, N. Kranz, and J. Maestu. 2007. Cultural factors as co-determinants of participation in river basin management. Ecology and Society 12(2): 24. [online] URL: http://www.ecologyandsociety.org/vol12/iss2/art24/

Evans, C., E. Abrams, R. Reitsma, K. Roux, L. Salmonsen, and P. P. Marra. 2005. The neighborhood nestwatch program: participant outcomes of a citizen-science ecological research project. Conservation Biology 19(3):589-594. http://dx.doi. org/10.1111/j.1523-1739.2005.00s01.x

Evely, A. C., M. Pinard, M. S. Reed and I. Fazey. 2011. High levels of participation in conservation projects enhance learning. Conservation Letters 4:116-126. http://dx.doi. org/10.1111/j.1755-263X.2010.00152.X

Fishbein, M., and I. Ajzen. 1975. Belief, attitude, intention and behavior: an introduction to theory and research. Addison-Wesley, Reading, Massachusetts, USA.

Glaser, B. 1992. Basics of grounded theory analysis. Sociology Press, Mill Valley, California, USA.

Goddard, M. A., A. J. Dougill, and T. G. Benton. 2010. Scaling up from gardens: biodiversity conservation in urban environments. Trends in Ecology and Evolution 25(2):90-98. [online] URL: http://homepages.see.leeds.ac.uk/ lecajd/ papers/Goddardetal.TREE.pdf http://dx.doi.org/10.1016/j. tree.2009.07.016

Goffman, E. 1967. Alienation from interaction. Pages 113137 in E. Goffman and J. Best. Interaction ritual: essays on face-to-face behaviour. Doubleday and Company, New York, New York, USA.

Gonzalez, C., A. Clemente, and K. A. Nielsen. 2009. Humannature relationship in mediterranean streams: integrating different types of knowledge to improve water management. Ecology and Society 14(2): 35. [online] URL: http://www. ecologyandsociety.org/vol14/iss2/art35/
Harrison, C. M., J. Burgess, and J. Clark. 1998. Discounted knowledges: farmers' and residents' understandings of nature conservation goals and policies. Journal of Environmental Management 54:305-320. http://dx.doi.org/10.1006/jema.1998.0242

Hinds, J., and P. Sparks. 2008.Engaging with the natural environment: the role of affective connection and identity. Journal of Environmental Psychology 28:109-120. http://dx. doi.org/10.1016/j.jenvp.2007.11.001

Hines, J. M., H. R. Hungerford, and A. N. Tomera. 1986. Analysis and synthesis of research on responsible proenvironmental behaviour: a meta-analysis. The Journal of Environmental Education 18(2):1-8. http://dx.doi. org/10.1080/00958964.1987.9943482

Horowitz, A. C. 2007.Naturalizing anthropomorphism: behavioral prompts to our humanizing of animals. Anthrozoos 20:23-35. http://dx.doi.org/10.2752/089279307780216650

Houde, N. 2007. The six faces of traditional ecological knowledge: challenges and opportunities for Canadian comanagement. Ecology and Society 12(2): 34. [online] URL: http://www.ecologyandsociety.org/vol12/iss2/art34/

Hungerford, H. R., and T. L. Volk. 1990. Changing learner behaviour through environmental education. The Journal of Environmental Education 21(3):8-21.

Kaufmann, J. C. 2008. L'Entretien compréhensif. Armand Colin, Paris, France.

Kelsey, E. 2003. Integrating multiple knowledge systems into environmental-decision-making: two case-studies of participatory biodiversity initiatives in Canada and their implications for conceptions of education and public involvement. Environmental Values 12:381-396. http://dx.doi. org/10.3197/096327103129341379

Kollmus, A., and J. Agyeman. 2002. Mind the gap: why do people act environmentally and what are the barriers to proenvironmental behaviour? Environmental Education Research 8(3):239-260. http://dx.doi.org/10.1080/13504620220145401

Ladkin, D. 2005. Does "restoration" necessarily imply the domination of nature? Environmental Values 14:203-219. http://dx.doi.org/10.3197/0963271054084911

Lindenberg, S., and L. Steg. 2007. Normative, gain and hedonic goal frames guiding environmental behavior. Journal of Social Issues 63:117-137. http://dx.doi.org/10.1111/ j.1540-4560.2007.00499.x

Meinhold, J. L., and A. J. Malkus. 2005. Adolescent environmental behaviors: can knowledge, attitudes, and selfefficacy make a difference? Environment and Behavior 37 (4):511-532. http://dx.doi.org/10.1177/0013916504269665

Millennium Ecosystem Assessment. 2005. Ecosystems and human well-being: biodiversity synthesis. World Resources 
Institute, Washington D.C., USA. [online] URL: http://www. maweb.org/documents/document.356.aspx.pdf

Miller, J. R. 2005. Biodiversity conservation and the extinction of experience. Trends in Ecology and Evolution 20:430-434. http://dx.doi.org/10.1016/j.tree.2005.05.013

Miller, J. R. 2006. Restoration, reconciliation, and reconnecting with nature nearby. Biological Conservation 127:356-361. http://dx.doi.org/10.1016/j.biocon.2005.07.021

Minteer, B. A., and J. P. Collins. 2005. Why we need an ecological ethics. Frontiers in Ecology and the Environment3:332-337.

Novacek, M. J. 2008. Engaging the public in biodiversity issues. Proceedings of the National Academy of Sciences of the United States of America 105:11571-11578. [online] URL: http://www.pnas.org/content/105/suppl.1/11571.full

Palmer, M. A., R. F. Ambrose, and N. LeRoyPoff. 1997. Ecological theory and community restoration ecology. Restoration Ecology 5:291-300. http://dx.doi.org/10.1046/ j.1526-100X.1997.00543.X

Pooley J. A., and M. O'Connor. 2000. Environmental education and attitudes: emotions and beliefs are what is needed. Environment and Behavior 32:711.

Prévot-Julliard A. C., J. Clavel, P. Teillac-Deschamps, and R. Julliard. 2012. The need for flexibility in conservation practices: exotic species as an example. Environmental Management, in press.

Pruneau, D., O. Chouinard, J. P. Musafiri, and C. Isabelle. 2000. Les facteurs qui influencent le désir d'action environnementale dans les communautés. Revue des sciences de l'éducation 21(2):395-414. http://dx.doi.org/10.7202/000128ar

Pyle, R. M. 2003. Nature matrix: reconnecting people with nature. Oryx 37:206-214. http://dx.doi.org/10.1017/ $\underline{\mathrm{S} 0030605303000383}$

Rickinson, M. 2001. Learners and learning in environmental education: a critical review of the evidence. Environmental Education Research 7(3):207-320. http://dx.doi. org/10.1080/13504620120065230

Rosenzweig, M. L. 2003. Win-win ecology. How the earth's species can survive in the midst of human enterprise. Oxford University Press, Oxford, UK.

Ross, N., D. Medin, J. D. Coley and S. Altran. 2003. Cultural and experimental differences in the development of folkbiological induction. Cognitive Development 81(1):2547. http://dx.doi.org/10.1016/S0885-2014(02)00142-9

Rozzi, R., F. Massardo, and C. B. Anderson. 2006. Ten principles for biocultural conservation at the southern tip of the Americas: the approach of the Omora. Ecology and Society
11(1):43. [online] URL: http://www.ecologyandsociety.org/ vol11/iss $1 /$ art43/

Ryan, R., and E. Deci. 2000. Self-determination theory and the facilitation of intrinsic motivation, social development, and well-being. American Psychologist 55:68-78. http://dx. doi.org/10.1037/0003-066X.55.1.68

Ryan, R., and E. Deci. 2002. Overview of self-determination theory: an organismic dialectic perspective. Pages 3-33 in R. Ryan and E. Deci, editors. Handbook of self-determination research. University of Rochester Press, Rochester, New York, USA.

Saunders, C. 2003. The emerging field of conservation psychology. Human Ecology Review 10:137-149.

Schmeller, D. S., P. Y. Henry, R. Julliard, B. Gruber, J. Clobert, F. Dziock, S. Lengyel, P. Nowicki, E. Déri, E. Budrys, T. Kull, K. Tali, B. Bauch, J. Settele, C. van Swaay, A. Kobler, V. Babij, E. Papastergiadou, and K. Henle. 2009. Advantages of volunteer-based biodiversity monitoring in Europe. Conservation Biology 23:307-316. http://dx.doi.org/10.1111/ j.1523-1739.2008.01125.x

Schultz, P. W. 2011. Conservation means behavior. Conservation Biology 25:1080-1083. http://dx.doi.org/10.1111/ j.1523-1739.2011.01766.x

Schwartz, M. W. 2006. How conservation scientists can help develop social capital for biodiversity. Conservation Biology 20(5):1550-1552. http://dx.doi.org/10.1111/j.1523-1739.2006.00421. $\underline{x}$

Searle, J. 1983. Intentionality: an essay in the philosophy of mind. Cambridge University Press, Cambridge, UK. http://dx. doi.org/10.1017/CBO9781139173452

Selman, P., C. Carter, A. Lawrence, and C. Morgan. 2010. Reconnecting with a recovering river through imaginative engagement. Ecology and Society 15(3): 18. [online] URL: http://www.ecologyandsociety.org/vol15/iss3/art18/

Staats, H. 2003. Understanding pro-environmental attitudes and behavior: an analysis and review of research based on the theory of planned behavior. Pages 171-201 in M. Bonnes, T. Lee, and M. Bonaiuto, editors. Psychological theories for environmental issues. Ashgate Press, Aldershot, UK.

Stedman, R. C. 2002. Toward a social psychology of place: predicting behavior from place-based cognitions, attitude, and identity. Environment and Behavior34(5):405-425. http://dx. doi.org/10.1177/0013916502034005001

Stern, P. C. 2000. New environmental theories: toward a coherent theory of environmentally significant behavior. Journal of Social Issues 56:407-424. http://dx.doi. org/10.1111/0022-4537.00175 
Storksdieck, M., K. Ellenbogen and J. E. Heimlich. 2005. Changing minds? Factors that influence freechoice learning about environmental conservation. Environmental Education Research 11(3):353-369. http://dx.doi.org/10.1080/1350462$\underline{0500081228}$

Strauss, A. L. 1987. Qualitative analysis for social scientists. Cambridge University Press, Cambridge, UK. http://dx.doi. org/10.1017/CBO9780511557842

Sturgis P., and N. Allum. 2004. Science in society: reevaluating the deficit model of public attitudes. Public Understanding of Science 13:55-74. http://dx.doi. org/10.1177/0963662504042690

Turner, W. R., T. Nakamura, and M. Dinetti. 2004. Global urbanization and the separation of humans from nature. Bioscience 54:585-590.

United Nations Environment Programme (UNEP). 2010. Global biodiversity outlook 3. Secretariat of the Convention on Biological Diversity, Montreal, Quebec, Canada.

Wells, N., and K. S. Lekies. 2006. Nature and the life course: pathways from childhood nature experiences to adult environmentalism. Children, Youth and Environments 16 (1):1-24.

Zimbardo, P. and E. B. Ebbesen. 1969. Influencing attitudes and changing behavior. Addison-Wesley, Reading, Massachusetts, USA. 
APPENDIX 1. Thematic guideline

Participation / motivations

Since when do you participate in the Garden Butterflies Watch program? Since when do you observe butterflies?

How did you discover the program?

Are you participating in other similar watching programs?

Why did you decide to observe? What are you motivations? What does it brings you?

Knowledge

What are your reactions and feelings when you observe butterflies?

Do you know the butterflies' species? What do you think about butterflies?

How do you perceive your participation in the program?

Did you observe differences about the butterflies' populations in your garden, according to the different years?

Are you interested in the annual results about butterflies provided by the Museum?

Relation to the garden

How often do you observe butterflies? What is you observation method?

How do you perceive your garden?

Did you consider special practices or changes in your garden, in relation with the participation in the program?

$\underline{\text { Social and communication }}$

Do you talk about your participation in the program? Do you interact with people, within the watching program or in a similar observation context? 


\section{APPENDIX 2. Quotes (original French version)}

1: «J'ai toujours été intéressé par tout ce qui était science. Bon là c'est vraiment très modeste, mais c'est l'idée de se dire qu'on peut participer justement en tant que non scientifique... » (Homme, quarantaine, Ile-de-France, marié, enfants, emploi dans le bâtiment)

2 : «Je suis d'un village d'ici où la nature on s'en fout complètement. Moi j'ai été élevé comme ça. On détruisait, les gens chassaient. On détruisait sans aucune espèce de retenue et les réflexes étaient restés. Même moi je les avais : bon il faut tailler, tondre, éliminer, etc. Même les insectes, enfin tout. » (Homme, cinquantaine, côte Méditerranéenne, marié, employé communal)

3 : «En fait, à partir du moment où j'ai regardé les papillons, j'ai appris, je les ai connus, et c'est vrai que je ne savais pas tout ce qu'il y avait comme diversité. Et ça je trouve que c'est une expérience extraordinaire » (Femme, cinquantaine, Ile-deFrance, mariée, enfants, sans profession)

$4:$ : On s'est aperçu que les papillons, on les voyait sans les voir. (...) Ça faisait partie de l'environnement. Et puis là on commence à observer, on essayait d'observer, on s'est pris au jeu. Alors au début c'était un peu difficile, on a acheté des livres très simples (...) Et c'est devenu un peu un jeu.» (Femme, soixantaine, côte Méditerranéenne, marié, enfants, sans profession)

5 : «Je fais ce que je peux pour les attirer [les papillons]. Ou en tout cas, les garder. Là, cette année, ce qui m'inquiète un peu, c'est que j'ai vu aucune chenille. J'en avais vu au mois de mars, plein de chenilles endormies. Et puis en fin de compte, j'ai pas vu les papillons qui ont éclos. (...) J'ai des petits coins un peu en friche, il y a les orties tout ça où je voudrais retrouver des chenilles. Il n'y a pas une chenille. (...) Donc c'est un peu inquiétant. Et j'ai des radis d'habitude et les piérides comptent là dessus. Là, j'ai des radis qui sont super sains. Donc, bon, j'attends le mois de juillet quoi! Pour être vraiment sûr.» (Femme, trentaine, Ile-de-France, marié, enfants, institutrice)

6: "Quand on est arrivés ici, on est arrivés il y a plus de vingt ans, il y avait énormément de crapauds. Bon, est ce que c'est l'été 2003 où il a fait extrêmement chaud... Je ne sais pas. Il n'y en a plus quasiment. On a énormément de grenouilles, des rainettes, et puis des grenouilles vertes aussi, mais des crapauds il n'y en a quasiment plus. (...) C'est très étrange. Je ne sais pas pourquoi.» (Femme, soixantaine, côte Méditerranéenne, mariée, emploi associatif)

7 : «Le fait de voir des papillons, pour moi c'est plutôt rassurant dans mon jardin. Je me dis : bon, si ils se portent bien, c'est quand même que ce qu'on fait va dans le bon sens. » (Femme, trentaine, Bretagne, éducatrice)

8 : «Les papillons aussi ça m'a quand même permis de mettre encore un peu plus d'aromatiques parce que bon... on en avait déjà un peu, mais pour pouvoir les observer je me suis dit «tiens on va en rajouter un peu», donc ça a modifié un peu la structure du jardin aussi.» (Homme, quarantaine, Bretagne, marié, enfants, emploi en aménagement du territoire)

9: «Je compte les papillons. C'est un petit peu un tableau de chasse, donc moins j'emploie de produits insecticides, plus j'ai de la chance d'observer les papillons ». (Femme, trentaine, Ile-de-France, mariée, enfants, institutrice)

10 : «Je suis vraiment amateur, je suis naturaliste, mais amateur. J'ai pas beaucoup le temps donc de prendre des cours et autres...donc je prends mes livres et puis ben j'apprend comme ça sur le terrain. Donc j'ai mes livres d'oiseaux (...) ben maintenant j'ai les livres de papillons évidemment » (Homme, quarantaine, Bretagne, marié, enfants, employé municipal)

11: Moi j'aime bien les prendre [guides naturalistes] avec des photos, parce que c'est vrai que les dessins, déjà enfin on ne voit pas... chacun de nous on a une vision particulière, tiens les couleurs par exemple ça peut varier d'un individu à l'autre (...) mais je l'emporte pas forcément en randonnée (...) Après à la maison, je consulte, (...) après si on retourne sur le site, on peut savoir, on peut reconnaître. (Femme, trentaine, côte Méditerranéenne, emploi dans le bâtiment)

12 : «Le petit dernier qui a cinq ans(...) Il connaît deux, trois quatre noms. Mais il arrive à les reconnaître. Donc, c'est vachement sympa, quoi! (...) Avant, quand il voyait un papillon, il disait : «Oh! C'est un papillon! ». Aujourd'hui, voilà : " 
ah, un paon du jour, une piéride, un citron... »» (Homme, quarantaine, Ile-de-France, marié, enfants, emploi dans le bâtiment)

13 : «On va voir parce qu'avant on n'avait pas de lotissement...Là, y a quarante maisons, donc on va voir si ça a un impact ou pas... bon ce qui y'a de sûr c'est que effectivement moi maintenant je laisse en friche une petite partie et on voit que tous les papillons viennent dessus. » (Femme, trentaine, Ile-de-France, mariée, enfants, géologue)

$14:$ : Quand on a le voisin qui traite et qui fait pas comme soi, si on va le voir en lui disant «oh lala, faut pas faire ça », ça marche pas. Faut plutôt l'amener chez soi en lui disant : "ben moi, je fais comme ça, parce que j'ai ça et ça », et en expliquant. Et après bon, soit il adhère, il n'adhère pas, mais au moins... » (Femme, cinquantaine, côte Méditerranéenne, mariée, enfants, chambres d'hôtes)

15 : «C'est bien d'avoir une conscience commune... (...) Mais moi, je trouve que ça manque un peu d'échange, bon des fois on se sent un peu seul quoi. Donc on est quand même à la recherche d'un mouvement qui serait plus large. Et puis aussi pour avoir des informations parce qu'en fait on est seul juge, enfin pour l'instant moi c'est mon cas quoi, on se dit "oui bon ben ça, c'est pas très bien je vais faire autrement » et ce serait bien d'avoir un regard extérieur, à la limite une analyse, parce qu'il y a des choses qu'on voit pas. Du fait qu'on est juge et partie, ça fausse un peu les résultats quoi. » (Femme, quarantaine, côte Méditerranéenne, mariée, enfants, informaticienne) 